\title{
The Indentation Size Effect (ISE) and the Speed of the Indenter Penetration into Test Piece
}

Jozef Petrík, Pavol Palfy, Peter Blaško, Lenka Girmanová, Milan Havlík

Faculty of Metallurgy, Technical University of Košice. Letná 9, 04200 Košice Slovakia. E-mail: jozef.petrik@tuke.sk

The aim of the submitted paper is to study the influence of the speed of the penetration of the indenter into the test piece ranging from $0.302 \mu \mathrm{m} \mathrm{s}^{-1}$ to $1.089 \mu \mathrm{m} \mathrm{s}^{-1}$ and applied load ranging from $10 \mathrm{~g}$ to $100 \mathrm{~g}$ on measured values of micro-hardness. Whereas certified reference material with defined specified hardness and its uncertainty was used as a test piece, the measurement involved indirect calibration of the tester. The influence of observed factors on measured value of the micro-hardness was evaluated by Meyer's index n, PSR method and by Analysis of Variance (ANOVA). The influence of the load on the measured value of micro-hardness is statistically significant and the relationship between applied load and micro-hardness manifests "reverse" ISE. The velocity has statistically significant effect on the micro-hardness. Meyer's index on average decreases with increasing of the speed.

Keywords: Micro-hardness, ISE, Speed of the indenter in the test piece, Load

\section{Acknowledgements}

This work was supported by the Slovak Grant Agency for Science VEGA 1/0595/16.

\section{References}

[1] MARTINOVSKÝ, M., MÁDL, J. (2015). Effect of Different Modifiers and Heat Treatment on Structure, Hardness and Microhardness of AlSi7Mg0.3 Alloy. In: Manufacturing Technology, Vol. 15, No. 4, pp. 604-610.

[2] ŤAVODOVÁ, M., KALINCOVÁ, D., KAŠTAN, R. (2016). The Research of Options for the Innovation Heat Treatment of the Tools for Coinage in Order to Increase their Lifetime. In: Manufacturing Technology, Vol. 16, No. 1, pp. 274-280.

[3] ŽIHALOVÁ, M., KALINCOVÁ, D., CAIS, J. (2015). Microstructural Analysis of Nickel Influence in Alsi10mgmn Alloy with Increased Iron Level. In: Manufacturing Technology, Vol. 15, No. 4, pp. 743-748.

[4] SANGWAL, K. SUROWSKA, B., BŁAZIAK, P. (2002). Analysis of the indentation size in the microhardness measurement of some cobalt-based alloys. In: Materials Chemistry and Physics, Vol. 77, No. 2, pp. 511-520.

[5] KORBA, P., PIL’A, J., FÖZÖ, L., CIBEREOVÁ, J. (2014). The use of visualization in aircraft design nodes by using CAX systems - 2014. In: SGEM 2014: 14th international multidiscilinary scientific geoconference : GeoConference on Informatics, Geoinformatics and Remote Sensing : conference proceedings : volume 1: 17-26, June, 2014, Albena, Bulgaria. - Sofia : STEF92 Technology Ltd., 2014 pp. 399-406.

[6] ŠČUREK, R., VÁLEK, D. (2014). Method of selecting the most important power lines in a transmission and distribution network, In: Przeglad elektrotechniczny, SIGMA-NOT, 11/2014, Poland, pp.152-1554.

[7] DAVID, J., ŠVEC, P., FRISCHER, R. (2013). Podpora údržby a řízení technologie bramového kontilití, In: METAL 2013, 22nd International Conference on Metallurgy and Materials, May 15th - 17th 2013, Hotel Voronez I, Brno Czech Republic, pp. 1650-1656.

[8] BUJNA, M., KOTUS, M., PRÍSTAVKA, M., FÖLDEŠIOVÁ, D. (2012). Analysis of hazard using FMEA. In: Technika v technológiách agrosektora 2012. Zborník vedeckých prác - Technics in agrisector Technologies, Nitra, SPU Nitra, pp. 32-35.

[9] KRÁliKOVÁ, R., PAULIKOVÁ, A., WESSELY, E. (2006). Modelling of production cycle for mechanical engineering processes - 2006. In: Industrial engineering - adding innovation capacity of labour force and entrepreneur. - Tallinn : University of technology, 2006, pp. 203-206.

[10] ISO 10 012:2003 Measurement management systems - Requirements for measurement processes and measuring equipment.

[11] International Vocabulary of Basic and General Terms in Metrology (1993). ISO. Geneva.

[12] VELES, P. (1985). Mechanical properties and testing of metals. Alfa/SNTL, pp. 307-320.

[13] PETRÍK, J., ŠOLC, M., MIKLOŠ, V. Applied Load and Calibration of the Hardness Tester (2014) In: Manufacturing Technology, Vol. 14, No. 2, pp. 228-234.

[14] SANGWAL, K. (2000), On the reverse indentation size effect and microhardness measurement of solids. In: Materials Chemistry and Physics. Vol. 63, No. 2, pp. 145-152. 
[15] STN EN ISO 6507-1:2005 Metallic materials. Vickers hardness test. Part 1: Test method.

[16] CHAKRABORTY, R. et al. (2010). Loading Rate Effect on Nanohardness of Soda-Lime-Silica, In: Metallurgical and Materials Transactions A, Vol. 41, No. 5, pp 1301-1312.

[17] GONG, J., WU. J., GUAN. ZH. (1999). Examination of the Indentation Size Effect in Low-load Vickers Hardness Testing of Ceramics, In: Journal of the European Ceramic Society. Vol. 19, No. 15, pp. 2625 - 2631.

[18] REN. X. J., HOOPER, R. M., GRIFFITHS, C. (2003). Indentation size effect in ceramics: Correlation with H/E, In: Journal of Materials Science Letters. Vol. 22 No. 15, pp. 1105-1106.

[19] NAVRÁTIL, V., NOVOTNÁ, J. (2009). Some problems of microhardness of metals. In. Journal of Applied Mathematics. Vol. 2, No. 3, pp. 241-244.

[20] EA-10/16 EA (2004) Guidelines on the Estimation of Uncertainty in Hardness Measurements. Annex Guideline to the Evaluation of the Uncertainty of the Brinell and the Vickers Measuring Method.

[21] STN EN ISO 6507-2:2005 Metallic materials. Vickers hardness test. Part 2: Verification and calibration of testing machines.

[22] CHANYA, CH., POJJANUT, B., PAITOON, D. (2009). Effect of Indentation Load and Time on Knoop and Vickers Microhardness Tests for Namel and Dentic, In: Materials Research, Vol. 12, No. 4, pp. 473-476.

[23] LI, H., BRADT, R. C. (1993). The microhardness indentation load/size effect in rutile and cassiterite single crystals. In: Journal of Materials Science. Vol. 28, No. 4, pp. 917-926.

[24] MICHELS, B. D., FRISCHAT, G. H. (1982). Microhardness of chalcogenide glasses of the system Se- Ge-As. In: Journal of Materials Science. Vol. 17, No. 2., pp. 329-334.

[25] KIM, H., KIM. T. (2002). Measurement of hardness on traditional ceramics. In: Journal of the European Ceramic Society, Vol. 22, No. 9-10, pp. 1437-1445.

[26] KONAR, R., PATEK, M. (2016) Prediction of Hardness and Residual Stresses of Dissimilar Weld Joint, In: Manufacturing Technology, Vol. 16, No. 2, pp. 365-371.

[27] MACHAKA, R. et al.. Advances in Materials Science and Engineering. 2011. [online]. [cited 29 November 2012 ]. Available from: http://www.hindawi.com/journals/amse/2011/539252/

[28] PETRÍK, J. (2014). Micro-hardness of heat treated carbon steel. In: Materials Science - Medžiagotyra, Vol. 20, No. 1, pp. 21-24.

[29] McDONALD, J. H. Handbook of Biological Statistics. [cited 07 May 2015]. Available from: http://www.biostathandbook.com/multipleregression.html

[30] AAKRE, A. (2004). Statistical functions and tools in Microsoft Excel. Trondheim, [cited 18 May 2015]. Available from: http://trafikk.info/evu_tt_oslo_2007/litteratur/excel_all_statistical_functions_and_tools_a5.pdf 